\title{
Provincial Power in a Centralizing China: The Politics of Domestic and International "Development Space"
}

\author{
Kyle A. Jaros and Yeling $\operatorname{Tan}^{\star}$
}

\begin{abstract}
A B S T R A C T
In a Xi Jinping era of rising central power and policy activism, what role is left for Chinese provinces? This article argues that, notwithstanding centralizing tendencies, China's recent economic development trajectory cannot be understood without taking into account the distinctive policy roles and priorities of provincial governments. Successive waves of governance restructuring have in many ways strengthened rather than weakened provincial authorities, reinforcing their role as central-local gatekeepers within China's political economy. In particular, we draw attention to the ways that provinces create and shape "development space" ( fazhan kongjian 发展空间) for different industries and localities and alter the contours of China's international economic engagement. We explore how provinces use their position as brokers of development space to concentrate investment in privileged areas of the economy while neglecting other aspects of development, deviating from central priorities in the process. Using case studies about industrial policy, rural development, and foreign economic relations, we show how-even in an era of centralism-provinces' developmental drive remains untamed.
\end{abstract}

$\mathrm{C}$ hina's provinces have faded into the analytical background during a $\mathrm{Xi}$ Jinping "new era" marked by the recentralization of political authority and the rollout of sweeping national policy initiatives. ${ }^{1}$ A fierce anticorruption campaign has brought officials into line with the Party center, and newly established leading small groups and central commissions have tightened their grip

*The authors are grateful for excellent feedback and suggestions on earlier versions of this essay from the editors and anonymous reviewers of The China Journal as well as from David J. Bulman, John A. Donaldson, Christina Maags, Victor Shih, Saul Wilson, and Audrye Wong. In addition, we would like to thank Vanessa Phan for her superb research assistance.

1. For discussions of resurgent centralism in China, see Cheng Li, Chinese Leadership in the Xi Jinping Era: Reassessing Collective Leadership (Washington, DC: Brookings Institution Press, 2016); Joseph Fewsmith, "The 19th Party Congress: Ringing in Xi Jinping's New Age," China Leadership Monitor, no. 55 (Winter 2018); Elizabeth Economy, The Third Revolution: Xi Jinping and the New Chinese State (New York: Oxford University Press, 2018).

Electronically published December 17, 2019

The China Journal, no. 83 (January 2020). (C) 2019 by The Australian National University. 1324-9347/2020/8301-0004. All rights reserved. DOI: 10.1086/706256 
on key bureaucracies. ${ }^{2}$ The central party-state has stepped up ideological controls and extended its reach into social and economic affairs across China. This more assertive leadership has, in turn, launched developmental programs of vast size on both the domestic and international stages. In 2013, Xi unveiled the Belt and Road Initiative (BRI) to link China with its Eurasian neighbors through corridors of modern economic infrastructure. In 2014, Beijing announced plans to build an integrated Beijing-Tianjin-Hebei (Jing jin ji 京津冀) megalopolis that is home to 110 million people. In 2015, the State Council put forward a Made in China 2025 strategy designed to secure China's status as a global power in advancedtechnology manufacturing.

As Anna Ahlers notes, tighter top-down control of politics and policy making might "seem to imply that we can say goodbye, for now, to the era of decentralization."3 Indeed, observers can point to several trends suggesting weakened provincial power under Xi. Since assuming office in 2012, Xi has carried out major reshufflings of provincial leaders, appointing many of his own allies. ${ }^{4}$ The anticorruption campaign has disrupted provincial power networks and increased pressure on subnational leaders to comply with central mandates. ${ }^{5}$ After 2012, the incidence of subnational policy experiments declined, suggesting a curtailment of local autonomy. ${ }^{6}$ Reinforcing this, the creation of powerful central commissions to oversee reform and economic affairs and the strengthening of top-down controls have made the party-state "hierarchy a more disciplined and efficient transmitter of top-level demands."

Yet, notwithstanding the emergence of a more assertive and ambitious center, China remains in fundamental ways a country of provinces. In this article, we argue that despite amped-up Party rhetoric and ambitious top-level initiatives, and contrary to the perception that decision making is now monopolized by $\mathrm{Xi}$, the

2. Wen-Hsuan Tsai and Wang Zhou, "Integrated Fragmentation and the Role of Leading Small Groups in Chinese Politics," China Journal, no. 82 (July 2019): 1-22.

3. Anna L. Ahlers, "Introduction: Chinese Governance in the Era of 'Top-Level Design,'” Journal of Chinese Governance 3, no. 3 (2018): 263.

4. Chen Gang, "Xi Jinping Reshuffles Provincial Leadership in China," East Asian Policy 8, no. 4 (2016): 14-23; "Xi's Landslide: A Provincial Shuffle Shows the Power of China's President," The Economist, May 27, 2017, https:/www.economist.com/china/2017/05/27/a-provincial-shuffle-shows-the-power-of-chinas -president.

5. Peter Lorentzen and Xi Lu, "Person Ties, Meritocracy, and China's Anti-Corruption Campaign," working paper (2018), https://www.aeaweb.org/conference/2019/preliminary/668? q = eNqrVipOLS7OzM8 LqSxIVbKqhnGVrAxrawGlCArI; Li Ling, "Politics of Anticorruption in China: Paradigm Change of the Party's Disciplinary Regime 2012-2017," Journal of Contemporary China 28, no. 115 (2019): $47-63$.

6. Sebastian Heilmann, "Leninism Upgraded: Xi Jinping's Authoritarian Innovations," China Economic Quarterly 20, no. 4 (2016): 15-22.

7. Barry Naughton, “Xi's System, Xi's Men: After the March 2018 National People's Congress," China Leadership Monitor 56 (2018): 8. 
capacity of provinces to influence economic policy is deeply entrenched and has even strengthened in certain respects. This is, at least in part, because of, rather than in spite of, political-administrative recentralization.

The Xi era is not the first time scholars have explored how recentralization affects the position of provinces in China's political economy. Andrew Mertha's concept of "soft centralization," Zheng Yongnian's "de facto federalism" framework, Jae Ho Chung's discussion of "selective recentralization," and John Donaldson's analysis of "weak" recentralization all speak to ways that provinces have retained policy influence through multiple post-1990s waves of recentralization. ${ }^{8}$ But previous scholarship has had less to say about the specific ways in which provinces affect policy outcomes under conditions of recentralization. How, and to what ends, do provinces exert policy influence in a more hierarchical political economy? What is distinctive about provincial policy making, and what are the pathways through which provinces shape outcomes across different realms of economic policy?

To address these questions, we present a new conceptualization of provincial power in a context of resurgent centralism. While building upon work that highlights the power that provincial governments derive from their position as intermediaries in the party-state hierarchy, we clarify how provinces exploit this position to influence economic policy outcomes. We argue that provincial governments play a pivotal role in mobilizing central state resources and targeting them toward particular localities and sectors. ${ }^{9}$ Acting as gatekeepers between the resource-rich central state and resource-hungry local actors, provinces have considerable control over the localities' "development space" (fazhan kongjian 发展空间)—that is, the privileged access to economic and institutional resources that cities and industries rely on for continued growth. We have adopted the term "development space" because it is already widely used by Chinese policy elites and scholars, as we will discuss. We will explain why provincial governments, in their pursuit of resources, policy influence, and tangible economic achievements, treat development largely as a problem of investment and use their gatekeeping powers to promote the very type of extensive (input-maximizing) growth that Beijing has attempted to curb. Although China scholars have long noted that subnational

8. See Andrew C. Mertha, “China's 'Soft' Centralization: Shifting Tiao/Kuai Authority Relations,” China Quarterly, no. 184 (2005): 791-810; Zheng Yongnian, De Facto Federalism in China: Reforms and Dynamics of Central-Local Relations (Singapore: World Scientific, 2007); Jae Ho Chung, Centrifugal Empire: CentralLocal Relations in China (New York: Columbia University Press, 2016); John Donaldson, "China's Administrative Hierarchy: The Balance of Power and Winners and Lowers with China's Levels of Government," in Assessing the Balance of Power in Central-Local Relations in China, ed. John Donaldson (Abingdon: Routledge, 2017), 76-104.

9. Here, we further develop ideas that appear in previous work of one of the coauthors; see Kyle A. Jaros, China's Urban Champions: The Politics of Spatial Development (Princeton, NJ: Princeton University Press, 2019), 57-58. 
governments' self-interested behavior distorts central policy agendas, ${ }^{10}$ highlighting the logic of development space helps to clarify why problematic outcomes persist and can even worsen in the context of renewed centralism.

We will provide evidence of how provinces' role as brokers of development space has shaped China's economic policy trajectory in recent decades. Case studies from three different policy areas show how this has influenced outcomes at various stages of the policy-making process and exacerbated problems of uncoordinated and uneven development. In industrial development, content analysis of policy documents across different government levels suggests that provincial authorities focus much more narrowly than central authorities on investment and megaprojects. This is particularly visible in industries such as the new energy vehicle (NEV) sector (i.e., electric vehicles), where province-level policies diverge significantly from central policies. In rural development, analysis of the content and targeting of provincial-administration-of-counties (PAC) reforms-which sought to free counties from the fiscal and/or administrative oversight of citiesshows provinces' ability to selectively alter counties' access to fiscal resources, policy support, and investment opportunities. Finally, our analysis of the BRI shows that provincial authorities have played a key role in shaping the contours of China's foreign economic policy and are capturing new development opportunities both within and beyond China's borders. We find that, ironically, even as China's leaders have adopted stronger measures to steer economic development nationally, they have continued to set in motion subnational dynamics they cannot fully control.

In what follows, we will first discuss how China's recentralizing reforms since the 1990s not only have failed to fully rein in provinces but have also empowered provinces through specific pathways. We next present our main arguments about the role of provinces as brokers of development space. We go on to present qualitative and quantitative evidence from three policy domains to illustrate our argument.

\section{PROVINCIAL EMPOWERMENT IN A RECENTRALIZING CHINA}

The question of provincial influence sits within the longer arc of governance decentralization and recentralization in post-reform China. The Deng era, particularly during the late 1980s and early 1990s, represented a heyday of provincial power. Faltering central authority, rising local protectionism, and the increasing decentralization of economic resources led observers to discuss the possibility of

10. See, for instance, David M. Lampton, "A Plum for a Peach: Bargaining, Interest, and Bureaucratic Politics in China," in Bureaucracy, Politics, and Decision Making in Post-Mao China, ed. Kenneth Lieberthal and David M. Lampton (Berkeley: University of California Press 1992), 33-58; Yasheng Huang, Inflation and Investment Controls in China: The Political Economy of Central-Local Relations during the Reform Era (Cambridge: Cambridge University Press, 1996). 
regional fragmentation or regime collapse. ${ }^{11}$ Since then, sequential moves by national leaders have recentralized political, administrative, and financial authority and curbed the risk of provincial breakaways. Efforts in the early and mid 1990s included the reinvigoration of the Party's organization and ideology, ${ }^{12}$ tighter personnel control, ${ }^{13}$ and sweeping fiscal reforms. These were followed in the late $1990 \mathrm{~s}$ and early 2000s by reforms to consolidate the central bureaucracy, banking system, and state-owned enterprise structure. ${ }^{14}$ A tilt toward economic statism in the following decade saw greater central intervention in economic and regional planning, ${ }^{15}$ investment and land-use regulation, ${ }^{16}$ and promotion of industrial "national champions." 17

Yet, as a rich body of scholarship makes clear, there has never been a zero-sum trade-off between central and provincial power. ${ }^{18}$ Although China's central partystate apparatus has strengthened in political and economic terms over the past quarter century, provincial authority has not necessarily weakened. Instead, precisely because Beijing has tightened vertical controls over resources and policy approvals and has undertaken more ambitious state program, provincial governments have grown more influential as intergovernmental gatekeepers.

One reason for provincial empowerment is that China's central party-state is chronically overextended, lacking sufficient organizational and informational capacity to administer localities or oversee policy implementation across a vast, multilevel political economy. ${ }^{19}$ Extensive delegation of policy and allocative decisions to provinces has been the norm. ${ }^{20}$ For example, even as China's mid- and late 1990s fiscal reforms clarified central-province revenue sharing rules, partially recentralized revenue collection, and instituted top-down fiscal transfers, the

11. See, e.g., discussion by contributors to David S. G. Goodman and Gerald Segal, eds., China Deconstructs: Politics, Trade and Regionalism (London; Routledge, 1994).

12. See David L. Shambaugh, China's Communist Party: Atrophy and Adaptation (Washington, DC: Woodrow Wilson Center Press; Berkeley: University of California Press, 2008).

13. Pierre F. Landry, Decentralized Authoritarianism in China: The Communist Party's Control of Local Elites in the Post-Mao Era (New York: Cambridge University Press, 2008).

14. See Dali L. Yang, Remaking the Chinese Leviathan: Market Transition and the Politics of Governance in China (Stanford, CA: Stanford University Press, 2004); Sebastian Heilmann, "Regulatory Innovation by Leninist Means: Communist Party Supervision in Chinas Financial Industry," China Quarterly 181 (2005): 1-21.

15. Sebastian Heilmann and Oliver Melton, "The Reinvention of Development Planning in China, 19932012," Modern China 39, no. 6 (2013): 580-628.

16. Barry Naughton, "The Assertive Center: Beijing Moves Against Local Government Control of Land," China Leadership Monitor, no. 20 (2007).

17. Sarah Eaton, "Political Economy of the Advancing State: The Case of China's Airlines Reform," China Journal, no. 69 (2013): 64-86.

18. See, e.g., Linda Chelan Li, Centre and Provinces-China 1978-1993: Power as Non-Zero-Sum (Oxford: Clarendon, 1998); Zheng, De Facto Federalism, 17-24.

19. For an extreme example, see a discussion of the small size of central offices overseeing regional plan implementation in Heilmann and Melton, "Reinvention of Development Planning," 607.

20. John A. Donaldson, "Provinces: Paradoxical Politics, Problematic Partners," in China's Local Administration: Traditions and Changes in the Sub-national Hierarchy, ed. Jae Ho Chung and Tao-chiu Lam (London: Routledge, 2010), 27-33. 
reforms allowed provincial authorities broad discretion over subprovincial fiscal arrangements. ${ }^{21}$ Similarly, efforts to strengthen vertical bureaucratic control over local enterprise administration and financial affairs yielded what Mertha calls "soft centralization"-recentralization to the provincial level rather than to Beijing. ${ }^{22}$ Notionally centralizing reforms that vested more regulatory and allocative powers with provinces were also seen in domains like land governance ${ }^{23}$ and industrial policy. ${ }^{24}$

A second reason for provincial empowerment is that central leaders have launched increasingly ambitious development initiatives since the turn of the twenty-first century but have delegated to provincial governments many of the choices about implementation and resource allocation. This has been the case for major policy programs like the Western Development campaign, the Revive the Northeast Old Industrial Base initiative, the establishment of Comprehensive Reform Pilot Zones, and the Strategic Emerging Industries plan. Entrusted with the task of implementation, provinces have gained access to new channels of fiscal support as well as considerable latitude for interpreting central goals. ${ }^{25}$

These center-province dynamics remain highly relevant, if insufficiently recognized, in the $\mathrm{Xi}$ era. On the one hand, as the $\mathrm{Xi}$ administration has sought to rein in subprovincial governments to address challenges such as local government debt and environmental pollution, central leaders have continued to employ "soft centralization"-style approaches, empowering provinces to enhance oversight of localities. For example, as the Xi administration took steps in 2014-15 to phase out nontransparent borrowing by local government financial vehicles, it authorized provincial governments to issue hundreds of billions of dollars' worth of bonds. ${ }^{26}$ On the other hand, much of the concrete implementation of signature Xi-era initiatives, such as the BRI, the Made in China industrial strategy, and Xiong'an New Area construction, has been delegated to provincial governments. For instance, planning and coordination of development for the Xiong'an New Area has largely been outsourced to Hebei Province, where the project is situated. ${ }^{27}$

21. Christine Wong, "Paying for Urbanization in China: Challenges of Municipal Finance in the TwentyFirst Century," in Financing Metropolitan Governments in Developing Countries, ed. Roy W. Bahl et al. (Cambridge, MA: Lincoln Institute of Land Policy, 2013), 273-309.

22. Mertha, "China's 'Soft' Centralization," 791-97.

23. You-tien Hsing, The Great Urban Transformation: Politics of Land and Property in China (Oxford: Oxford University Press, 2010), 96-97.

24. Chung, Centrifugal Empire, 23-24.

25. Ibid., 95; Heilman and Melton, "Reinvention of Development Planning," 594.

26. W. Rafael Lam and Wang Jingsen, "China’s Local Government Bond Market," International Monetary Fund Working Paper (2018), https://www.imf.org/en/Publications/WP/Issues/2018/09/28/China-s-Local -Government-Bond-Market-46275.

27. State Council, "Guowuyuan guanyu Hebei xiong'an xinqu zongi guihua 2018-2035 nian de pifu" [State council reply regarding Hebei Xiong’an New Area master plan, 2018-2035] (2018), http:// www.gov.cn/zhengce/content/2019-01/02/content_5354222.htm. 
In these ways, the practices of the $\mathrm{Xi}$ era display a continuation and even intensification of existing dynamics rather than a sharp break with previous years.

However, to argue that provinces remain powerful actors is not the same as showing how they matter. Recent scholarship has had surprisingly little to say about the precise nature and consequences of provincial power in the context of recentralization. What types of power do provinces wield? How does the exercise of such provincial power affect outcomes across different economic realms and stages of the policy-making process? To what extent do provincial actions align with central priorities as opposed to distorting them?

\section{PROVINCES AND THE BROKERING OF DEVELOPMENT SPACE}

Our core argument is twofold. First, we contend that the intermediary position that provinces occupy in China's political economic hierarchy enables them to play a gatekeeping role, selectively influencing the development space that different localities and industries enjoy. Second, we argue that this policy influence shows up in a bias toward excessive and unevenly targeted investment that exacerbates China's problems of unbalanced development.

Beijing's efforts at recentralization since the 1990s have produced a political economy that many scholars describe as "state capitalist." 28 Such a system combines bottom-up market dynamism with top-down state intervention: while enterprises and local governments are the main growth drivers, higher-level policies shape the structure of opportunities available to specific localities or industries. As resources and regulatory controls are consolidated upward, garnering adequate development space has become a constant concern for China's growing cities and industries. Chinese policy makers use this term in both a concrete and an abstract manner, and our definition of development space as privileged access to the economic and institutional resources needed for growth captures both types of usages. ${ }^{29}$ China's various types of designated development zones-from the

\footnotetext{
28. See, e.g., Kellee S. Tsai and Barry Naughton, "Introduction," in State Capitalism, Institutional Adaptation, and the Chinese Miracle, ed. Kellee S. Tsai and Barry Naughton (Cambridge: Cambridge University Press, 2015), 1-24.

29. For example, Jiangxi provincial Party secretary Su Rong in 2012 called for supporting development of the provincial capital city, saying that "as long as it is good for Nanchang's development, any power that can be handed down should be, and we should give Nanchang more development autonomy and development space" (Xinhuawang [Xinhua Net], "Su Rong: Ju quan sheng zhi li ba nanchang dazao cheng hexin zengzhangji” [Su Rong: Use the strength of the whole province to build up Nanchang into a new growth pole], November 5, 2012, http://www.jx.xinhuanet.com/nchxzzj/lindao/2012-11/05/c_113611621.htm). In a different context, a 2011 op-ed by a Ministry of Finance official explained how Chinese investment in overseas infrastructure and industry would pay off in time, noting that "it will in fact open up broad development space for China" ("21 shiji jingji baodao" [21st century economic herald], "Zhongguo kaifang xin zhanlve” [A new strategy for China’s opening up], August 15, 2011, http://www.cnki.com.cn).
} 
original four Special Economic Zones to contemporary New Areas-are physical embodiments of the idea of development space. But the concept applies equally to state plans or policies that give advantages to certain sectors or locations, and to informal practices that influence economic actors' scope for growth.

Chinese cities and counties occupy the front line of development, interacting closely with firms and engaging directly with the tasks of urban and industrial development. ${ }^{30}$ While such subprovincial actors are key beneficiaries of development space, they have limited means to secure it on their own. They continually look to higher levels for access to the various elements that constitute development space-land quotas for construction use, fiscal transfers, regulatory permissions, and so on-over which, as discussed earlier, Beijing has delegated significant discretion to provinces. This situates provinces in a crucial position between Beijing and localities as the main brokers of development space. Figure 1, below, illustrates this gatekeeping role.

Their brokering role gives provincial authorities influence with the central government as well as leverage over localities. Provincial leaders' intermediary position enables them to lobby Beijing for special policies or designations. ${ }^{31}$ Working at the interstices of different administrative levels and systems, province-level actors are able to penetrate central decision-making processes and play an entrepreneurial role in policy-making. ${ }^{32}$ At the same time, provinces oversee prefecturelevel as well as many county-level governments and influence their access to financial and physical resources. ${ }^{33}$ Provinces assign land conversion and usage quotas, structure subprovincial fiscal arrangements, and shape access to state financing. ${ }^{34}$ They play a key role in overseeing state- and province-level development zones that offer concentrated resources for industry. ${ }^{35}$ And provinces are instrumental in

30. Fubing Su and Ran Tao, “The China Model Withering? Institutional Roots of China's Local Developmentalism," Urban Studies 54, no. 1 (2017): 230-50.

31. David S. G. Goodman, "The Provincial First Party Secretary in the People's Republic of China, 1949-1978: A Profile," British Journal of Political Science 10, no. 1 (1980): 39-74; David Zweig, Internationalizing China: Domestic Interests and Global Linkages (Ithaca, NY: Cornell University Press, 2002), 80-81.

32. Tim Summers, Yunnan-a Chinese Bridgehead to Asia: A Case Study of China's Political and Economic Relations with Its Neighbours (Oxford: Chandos, 2013), 9-11; 26; Kyle A. Jaros, "Rethinking Subnational Government Capacity in China," Journal of Chinese Governance 1, no. 4 (2016): 633-53.

33. A small subset of localities, most notably China's major provincial cities, enjoy more direct fiscal and administrative links to the central government. However, the vast majority of localities must work through their provincial-level superiors, and even deputy-provincial cities' development prospects can be severely impaired when provincial authorities withhold support. See Dorothy J. Solinger, "Despite Decentralization: Disadvantages, Dependence and Ongoing Central Power in the Inland-the Case of Wuhan," China Quarterly, no. 145 (1996): 1-34.

34. Gu Chaolin, Zhao Min, and Zhang Jingxiang, Shengyu chengzhenhua: Zhanlve guihua yanjiu [Provincial urbanization: Strategic planning research] (Nanjing: Southeastern University Press, 2012); Taiyang Zhong, Bruce Mitchell, Steffanie Scott, Xianjin Huang, Yi Li, and Xiao Lu, "Growing Centralization in China's Farmland Protection Policy in Response to Policy Failure and Related Upward-Extending Unwillingness to Protect Farmland since 1978," Environment and Planning C: Politics and Space 35, no. 6 (2017): 1075-97.

35. Zweig, Internationalizing China, 80-81. 


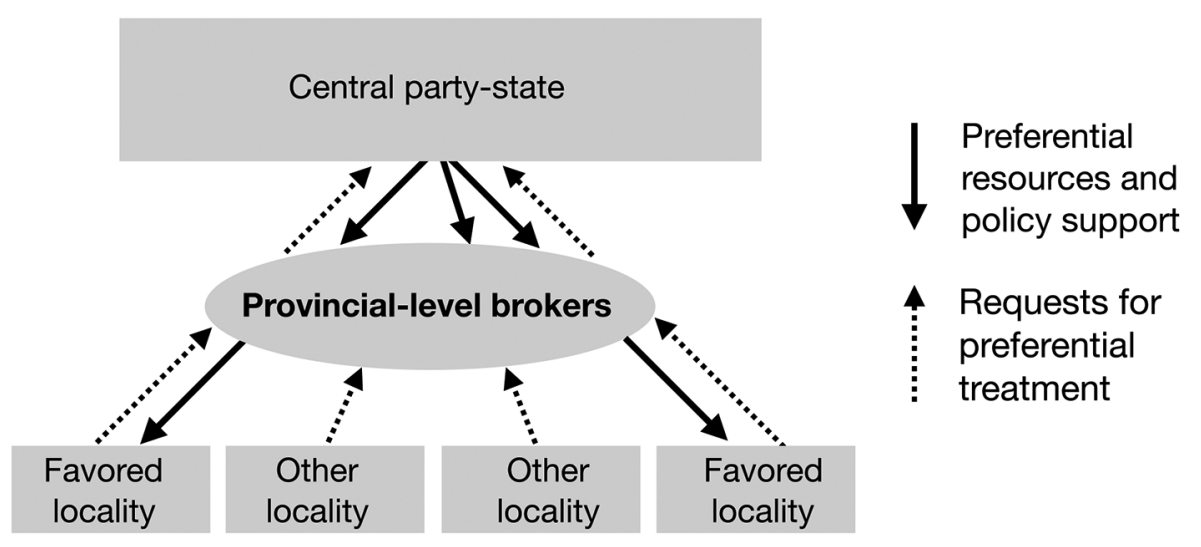

Figure 1. Provinces as gatekeepers

building translocal infrastructure such as roads, rail and utilities networks. ${ }^{36}$ If anything, provinces' brokering role has become enhanced in the Xi era, because subprovincial governments' maneuvering room has been reduced, while new resources have become available through central state initiatives.

However, our argument is not simply that provincial authorities wield considerable power as brokers of development space. We also argue that the way in which provinces use this power contributes to undesired policy outcomes. Far from being neutral central-local brokers, provincial governments are biased by their own capabilities and interests toward an extensive (input-maximizing) development mode, leading to excessive investment and unbalanced growth.

For provincial governments, economic development-a multifaceted challengeis often reduced to a problem of resource mobilization. Instead of focusing on qualitative questions of institutional improvement, technical upgrading, or managerial innovation, provinces often treat development as a quantitative problem of investment. As the following sections will show, many provincial policies assume that stronger economic growth follows mechanically from higher inputs of economic resources and political capital, betraying a bias toward extensive rather than intensive (efficiency-maximizing) development. Indeed, the very term "development space" implies expansive growth, and occurs frequently in the regulations of province-level governments. A search on www.pkulaw.cn, a database of Chinese government policies, found over 8,660 provincial documents that contain this term.

This conflation of economic development with resource mobilization is closely related to provinces' policy capabilities. China's provinces are not in a position to

36. Kun-chin Lin, "The Political Economy of Rapid Transport Infrastructure Expansion in China," CRP Working Paper no. 3 (2012); Guowen Dai, “The Impact of Policy Networks on the Urbanisation around High-Speed Railway Stations in China: The Case of Wuhan," Environment and Planning C: Government and Policy 33 (2015): 533-51. 
define the basic objectives of economic development; this is the center's prerogative. Nor can they control most economic activities on the ground; it is the subprovincial governments that play a more hands-on role in engaging with business enterprises. Insofar as provinces' intermediate position empowers them to mobilize and channel economic and policy resources, it is natural that provincial policy makers come to privilege such an interpretation of development.

Just as provincial authorities conceptualize economic development in a way that reflects their capabilities, they pursue development opportunities with a view toward their own interests. Although provinces ultimately answer to Beijing, they are powerful entities that do not necessarily act as faithful agents. ${ }^{37}$ Provincial leaders engage in fierce competition with other provinces for power and resources in pursuit of their own bureaucratic self-interest ${ }^{38}$ and political promotion, ${ }^{39}$ and in pursuit of rent-seeking, ${ }^{40}$ faction-building, and patronage-allocation opportunities. ${ }^{41}$ To expand their resource bases and outperform their counterparts, provincial leaders relentlessly pursue growth opportunities, seeking to quickly convert state support into tangible economic achievements that will build local support bases and impress their patrons in Beijing and outside investors. Following this logic, provinces direct resources to a subset of strategic locations and industries with high political profiles and near-term growth potential, contributing to unbalanced development. For instance, provincial governments tend to favor highly visible major metropolitan areas over smaller cities, ${ }^{42}$ and they tend to shower disproportionate amounts of investment on designated strategic industries. ${ }^{43}$ In many cases, large-scale projects that concentrate capital inputs are pursued with limited regard to cross-provincial externalities and national-level consequences.

\section{HOW PROVINCES SHAPE AND DISTORT DEVELOPMENT POLICY ACROSS DIFFERENT REALMS}

Our case studies span the $\mathrm{Hu}$ Jintao and Xi Jinping eras, demonstrating important continuities over time rather than a radical break in provincial influence on

37. Zheng, De Facto Federalism, 63.

38. Huang, Inflation and Investment Controls, 146-49; Jiang Xu, "Governing City-Regions in China: Theoretical Issues and Perspectives for Regional Strategic Planning," Town Planning Review 79, no. $2 / 3$ (2008): 157-85.

39. Zhiyue Bo, Chinese Provincial Leaders: Economic Performance and Political Mobility since 1949 (Armonk, NY: Sharpe, 2002).

40. Minxin Pei, China's Crony Capitalism: The Dynamics of Regime Decay (Cambridge, MA: Harvard University Press, 2016).

41. Victor Shih, Christopher Adolph, and Mingxing Liu, "Getting Ahead in the Communist Party: Explaining the Advancement of Central Committee Members in China," American Political Science Review 106, no. 1 (2012): 166-87.

42. Jaros, China's Urban Champions.

43. Dan Prud'homme, "Dynamics of China's Provincial-Level Specialization in Strategic Emerging Industries," Research Policy 45, no. 8 (2016): 1586-1603. 
Table 1. Overview of Cases

\begin{tabular}{|c|c|c|c|}
\hline Issue Area & Industrial Policy & Rural Development & Foreign Economic Policy \\
\hline $\begin{array}{l}\text { Stage of policy } \\
\text { influence }\end{array}$ & Implementation & Experimentation & Formulation \\
\hline $\begin{array}{l}\text { Manifestation of } \\
\text { push for "develop- } \\
\text { ment space" }\end{array}$ & $\begin{array}{l}\text { Diversion of } \\
\text { resources toward } \\
\text { investment and } \\
\text { large-scale projects }\end{array}$ & $\begin{array}{l}\text { Channeling of prefer- } \\
\text { ential policies } \\
\text { toward already- } \\
\text { privileged counties }\end{array}$ & $\begin{array}{l}\text { Growth promotion fo- } \\
\text { cused on cross-border } \\
\text { trade and investment } \\
\text { opportunities }\end{array}$ \\
\hline $\begin{array}{l}\text { Unexpected } \\
\text { consequence }\end{array}$ & $\begin{array}{l}\text { Duplication, excess } \\
\text { capacity, distortion } \\
\text { of national policy }\end{array}$ & $\begin{array}{l}\text { Exacerbation of } \\
\text { regional inequality }\end{array}$ & $\begin{array}{l}\text { National policy content } \\
\text { skewed toward } \\
\text { provincial interests in } \\
\text { large-scale infrastruc- } \\
\text { ture and high-profile } \\
\text { projects }\end{array}$ \\
\hline
\end{tabular}

development policy. As the overview in table 1 shows, these cases reveal similarities in the developmental approaches that provinces adopt across different policy realms, as well as commonalities in the impact they have on different stages of the policy-making process. In each case, provincial authorities are closely involved in shaping the resources and policy support available to specific localities or sectors. In addition, we show how, in each domain, provincial efforts to mobilize development space for localities and industries have exacerbated problems of excessive investment and unbalanced growth. This perverse influence of provinces has grown increasingly visible over time, as the central government has become more focused on macroeconomic rebalancing and subprovincial units have faced more constraints on their policy autonomy.

Before proceeding, it is important to clarify that our goal is to capture a broad but underappreciated tendency in China's economy rather than to highlight and explore interprovincial variations. There are undoubtedly differences across provinces and issue areas in the extent to which provincial authorities are able to create and shape development space and in the specific ways in which provinces implement development policy. This variation lies beyond the scope of this essay, but our assumption is that the dynamics we highlight are likely to be more pronounced in places where provincial authority is strong relative to other administrative levels. ${ }^{44}$

44. For a discussion of variations in province-level strength, see Donaldson, "Provinces"; and Jaros, China's Urban Champions. 


\section{Industrial Development: How Provinces Feed the Investment Hunger of Firms and Localities}

For many years, central policy makers have voiced concerns about China's runaway industrial investment and unbalanced economic structure. Heavy reliance on investment as a growth driver has generated a variety of problems, and since the mid-2000s the central government has called for shifting to a consumptionbased growth model and curbing excess capacity in various industries. To achieve this, Beijing has imposed stricter planning controls on new projects and intensified the use of industrial policy frameworks. ${ }^{45}$ The central government has also promulgated a series of ambitious industrial restructuring and upgrading strategies, including a 2006 Medium- and Long-Term Plan on the Development of Science and Technology, the 2015 Made in China 2025 plan, and the Supply-Side Structural Reform (SSSR) program unveiled in 2016. As Beijing has worked to curb industrial overcapacity and guide structural transformation, however, it has had to contend with subnational authorities who rely on investment to power their local economies and political patronage networks.

Whereas scholars often point to the role of city and county governments in promoting excessive investment, ${ }^{46}$ it is important also to highlight the role of provinces. Although plans like Made in China 2025 and SSSR have been formulated nationally and are being guided by central leading small groups, Beijing has delegated much of the recent work of industrial restructuring to provinces. In the case of Made in China 2025, subnational entities "actually determine the pace and direction of smart manufacturing growth." ${ }^{47}$ Similarly, for SSSR, "the actual implementation is done by provincial governments, who have the staff and experience to carry through economics-related policies." 48 Provinces' role in implementation enables them to place their own pro-investment stamp on industrial policies.

To show the influence of province-level priorities on industrial policies, we examine textual information from a corpus of industry regulations issued by all three administrative levels from 1978 to 2014. These data, originally gathered by one of the co-authors, Yeling Tan, were collected by web-scraping the results of search requests in www.pkulaw.cn. ${ }^{49}$ Using these regulations, we assess the prevalence of terms associated with an extensive, input-based growth model

45. Sebastian Heilmann and Oliver Melton, "The Reinvention of Development Planning in China, 19932012," Modern China 39, no. 6 (2013): 580-628.

46. See, for instance, Su and Tao, "The China Model Withering?"

47. Jost Wübbeke, Mirjam Meissner, Max J. Zenglein, Jaqueline Ives, and Björn Conrad, "Made in China 2025," Mercator Institute for China Studies 2 (2016): 24.

48. Barry Naughton, "Supply Side Structural Reform at Mid-Year: Compliance, Initiative, and Unintended Consequences," China Leadership Monitor 51 (2016): 1.

49. The regulations collected are sector-specific and include national development plans for a given industry as well as related policies issued by central and subnational agencies of all sizes. The corpus comprises 43,069 documents across 128 manufacturing sectors; for more details, see Yeling Tan, "State Strategies under Global Rules: Chinese Industrial Policy in the WTO Era” (doctoral diss., Harvard University, 2017). 
across central, provincial, and local regulations at the two-digit industry level. We use the terms “develop(ment)” (fazhan 发展), “invest(ment)” (touzi 投资), and "project" (xiangmu 项目), which suggest a focus not just on growth but specifically on activities that are capital-intensive in nature ("investment") and can deliver tangible results (as with a "project").$^{50}$ As the salience of provinces' development space logic may vary over time and across industries, we examined the prevalence of these key words across the 1978-2014 period and across 29 aggregated industry clusters. If our argument about the provincial bias toward extensive development is correct, we should observe these key words being deployed more frequently in provincial regulations relative to central or local regulations. Across industries, we should also observe these words being adopted more frequently in capital and technology-intensive industries.

Table 2 summarizes our analysis, showing which administrative levels used key words most frequently in their regulations. A coding of "Central" means that the central government had the highest prevalence in using a word in the 1978-2014 time period, while a coding of "Provincial" indicates provincial prevalence, and "Local" indicates local—that is, subprovincial-government prevalence; ellipsis points (...) indicate that there is no clear trend in the data. ${ }^{51}$

The table shows that provinces are the highest-frequency user of these keywords. Indeed, 30 out of 90 cells are coded "Provincial," "Provincial and Local," or "Provincial and Central," far more than the 11 cells in which just "Local" appears and the five cells in which just "Central" appears. This analysis thus reveals that a rhetorical tendency to equate development with investment and investment projects is especially strong at the provincial level. Additionally, table 2 shows that the industries coded "Provincial" across all key words tend to be-as our argument would expect-capital-intensive and high-tech sectors, such as transportation, electrical machinery, and communications equipment. By way of illustration, figures 2 and 3 show the prevalence of these key words in the transportation equipment industry in the 1978-2014 period. ${ }^{52}$ The figures show that central government regulations use the words "investment" and "project" more frequently in the 1980s and 1990s, but that the words become more prevalent in provincial regulations after the late 1990s. This trend is consistent with our argument that economic policy centralization-which has been occurring since the 1990s-has the counterintuitive effect of stimulating, rather than dampening, provincial developmentalism.

50. Of course, the word "project" holds a variety of meanings in different contexts. Because this chart measures the word's prevalence in industry regulations, it can be interpreted here as an indicator of an investment-driven approach to growth.

51. This coding was conducted by plotting the prevalence of each word in central, provincial, and local government regulations over the 1978-2014 period and visually assessing if the word prevalence is persistently higher or rising for one level of administration compared with other levels within this time period.

52. We focus on the transportation industry, as its capital and technology-intensive characteristics make it a prime candidate for many provincial governments to deploy their development space logic to growth. 
Table 2. Government Level with Most Frequent Use of Terms Related to Developmental Space

\begin{tabular}{|c|c|c|c|}
\hline \multirow[b]{2}{*}{ Industry } & \multicolumn{3}{|c|}{ Term } \\
\hline & Develop (ment) & Invest(ment) & Project \\
\hline Agro-food processing & Local & .. & Provincial \\
\hline Food manufacturing & $\ldots$ & $\ldots$ & Central \\
\hline Beverage manufacturing & Local & Provincial & Provincial \\
\hline Tobacco & $\cdots$ & Central & Provincial \\
\hline Textile & Local & $\cdots$ & $\ldots$ \\
\hline $\begin{array}{l}\text { Textiles and clothing, footwear, } \\
\text { headgear manufacturing }\end{array}$ & $\ldots$ & $\cdots$ & $\cdots$ \\
\hline $\begin{array}{l}\text { Leather, fur, feathers (down) } \\
\text { and its products }\end{array}$ & $\cdots$ & $\cdots$ & $\cdots$ \\
\hline $\begin{array}{l}\text { Wood processing and wood, } \\
\text { bamboo, rattan, brown, grass } \\
\text { products }\end{array}$ & $\cdots$ & $\cdots$ & $\cdots$ \\
\hline Furniture manufacturing & $\ldots$ & $\ldots$ & $\ldots$ \\
\hline Paper and paper products & $\ldots$ & Provincial & Provincial \\
\hline $\begin{array}{l}\text { Printing, reproduction of recording } \\
\text { media }\end{array}$ & $\cdots$ & $\cdots$ & $\cdots$ \\
\hline Sporting goods manufacturing & $\ldots$ & & \\
\hline $\begin{array}{l}\text { Petroleum processing, coking and } \\
\text { nuclear fuel processing }\end{array}$ & Provincial & Central & Central and provincial \\
\hline $\begin{array}{l}\text { Chemical materials and chemical } \\
\text { products manufacturing }\end{array}$ & $\cdots$ & $\cdots$ & $\cdots$ \\
\hline Pharmaceutical manufacturing & Provincial and local & $\ldots$ & $\ldots$ \\
\hline Chemical fiber manufacturing & $\cdots$ & $\ldots$ & $\ldots$ \\
\hline Rubber & $\ldots$ & Provincial & $\ldots$ \\
\hline Plastic products & $\ldots$ & Provincial & $\ldots$ \\
\hline Nonmetallic mineral products & $\ldots$ & Provincial & Provincial \\
\hline $\begin{array}{l}\text { Ferrous metal smelting } \\
\text { and rolling processing }\end{array}$ & $\cdots$ & $\cdots$ & $\cdots$ \\
\hline $\begin{array}{l}\text { Nonferrous metal smelting } \\
\text { and rolling processing }\end{array}$ & Provincial and local & $\ldots$ & Provincial and local \\
\hline Fabricated metal products & Provincial and local & $\cdots$ & Provincial \\
\hline General equipment manufacturing & Provincial & Provincial & Provincial \\
\hline Special equipment manufacturing & $\cdots$ & & Central \\
\hline
\end{tabular}


Table 2 (Continued)

\begin{tabular}{|c|c|c|c|}
\hline \multirow[b]{2}{*}{ Industry } & \multicolumn{3}{|c|}{ Term } \\
\hline & Develop(ment) & Invest(ment) & Project \\
\hline $\begin{array}{l}\text { Transportation equipment } \\
\text { manufacturing }\end{array}$ & Provincial and local & Provincial & Provincial \\
\hline $\begin{array}{l}\text { Electrical machinery and equipment } \\
\text { manufacturing }\end{array}$ & Provincial and local & Provincial & Provincial \\
\hline $\begin{array}{l}\text { Communications equipment, } \\
\text { computers and other electronic } \\
\text { equipment manufacturing }\end{array}$ & Provincial and local & $\ldots$ & Provincial \\
\hline $\begin{array}{l}\text { Instrumentation and culture, office } \\
\text { machinery manufacturing }\end{array}$ & $\ldots$ & $\cdots$ & Provincial and local \\
\hline Handicrafts and other manufacturing & $\ldots$ & $\ldots$ & $\ldots$ \\
\hline $\begin{array}{l}\text { Waste resources and materials } \\
\text { recycling processing }\end{array}$ & $\cdots$ & $\cdots$ & $\cdots$ \\
\hline
\end{tabular}

Note: “. . ." indicates no clear trend in the data.

Delving more deeply into the transportation sector, the provincial government's role as a broker of development space and its bent toward extensive development can be seen through a comparison of central and provincial policies in the new energy vehicle (NEV) industry. The State Council issued a national NEV industrial plan in 2012, emphasizing priorities such as environmental sustainability and industrial transformation. ${ }^{53}$ While the plan prioritized technological innovation, this was to occur within a holistic industrial system. Fostering this would require not just vehicle production but also the establishment of a regulatory infrastructure, from standards-setting to intellectual property rights protection. The plan called for fostering "a group of high-quality NEV service enterprises" such as in vehicle leasing, marketing and after-sales support. The plan also explicitly warned against the type of input-maximizing approach that we argue is preferred by provinces. The policy stated that NEV production capacity should be "rationally developed" based on "the actual needs of industrial development and industrial policy requirements" and to "prevent blindly making low-quality investments and duplicating construction." S4 Similarly, the construction of charging stations was to be incorporated into a "comprehensive urban transportation system plan." In other

53. State Council, "Guanyu yinfa jieneng yu xinnengyuan qiche chanye fazhan guihua (2012-2020 nian) de tongzhi" [Circular on the development plan for the energy-saving and new energy vehicle industry (2012-2020)] (2012), www.gov.cn/zwgk/2012-07/09/content_2179032.htm.

54. Ibid. 


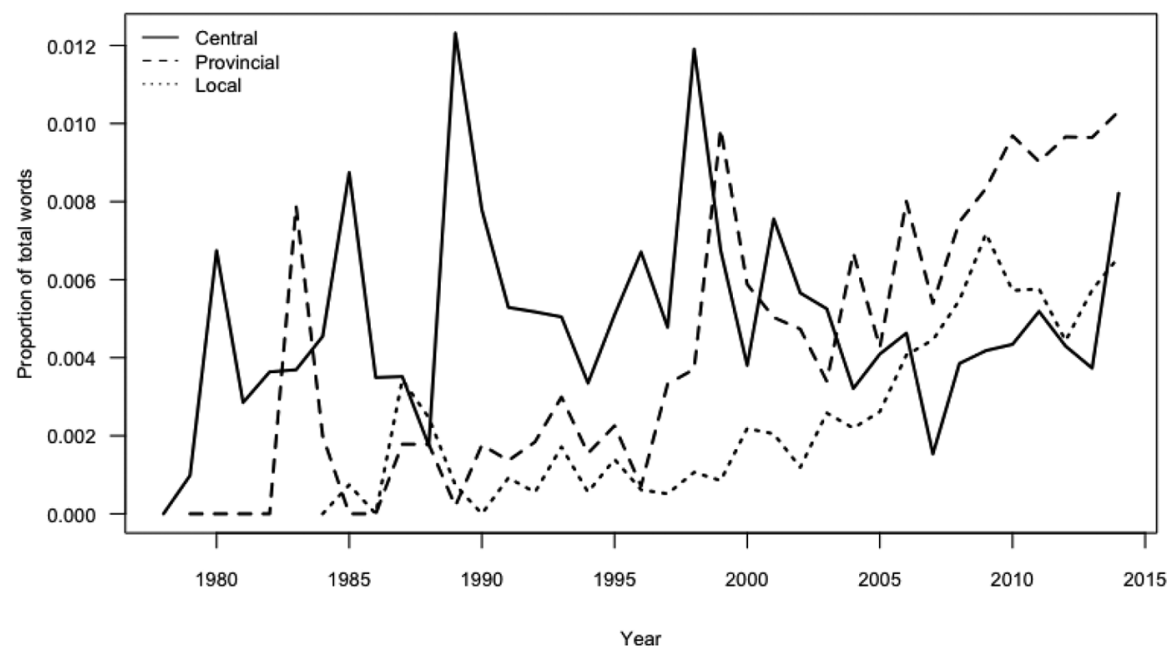

Figure 2. Prevalence of the word project in central, provincial, and local transportation equipment industry regulations.

words, the national industrial policy emphasized NEV production in the context of services development and regulatory enhancement-a systems-level approach that explicitly warned against a development space logic.

That same year, Hebei's provincial government issued its guidelines for implementing the State Council's NEV policy. ${ }^{55}$ A close comparison of this policy with the national guidelines reveals Hebei's adoption of a production-focused and investment-driven interpretation of the national plan. Under the "Development Goals" section of the Hebei policy, the stated first "main task" was to "rely on existing industrial bases to build six big industrial bases" for NEVs. In other words, production capacity was to be expanded in designated bases ranging from the provincial capital Shijiazhuang to development zones such as Caofeidian. This designation of specific production zones illustrates the province's crucial brokering role, translating national policies into concrete investment plans and channeling resources to favored localities. While the State Council policy emphasized a holistic, systems-based approach to NEV development, the Hebei policy emphasized the need to "expand the scale of the industry" by "actively supporting existing enterprises, quickly promoting the construction of major projects, and supporting qualified enterprises to become bigger and stronger." It also favored "vigorously carrying out investment promotion, actively introducing strategic investors, and striving to draw NEV and key component enterprises from home and

55. Hebei Provincial Government, "Guanyu guanche luoshi guojia jieneng yu xinnengyuan qiche chanye fazhan guihua de shishi yijian" [Opinion on implementing the national energy-saving and new energy vehicle industry development plan] (2012), http://pkulaw.cn. 


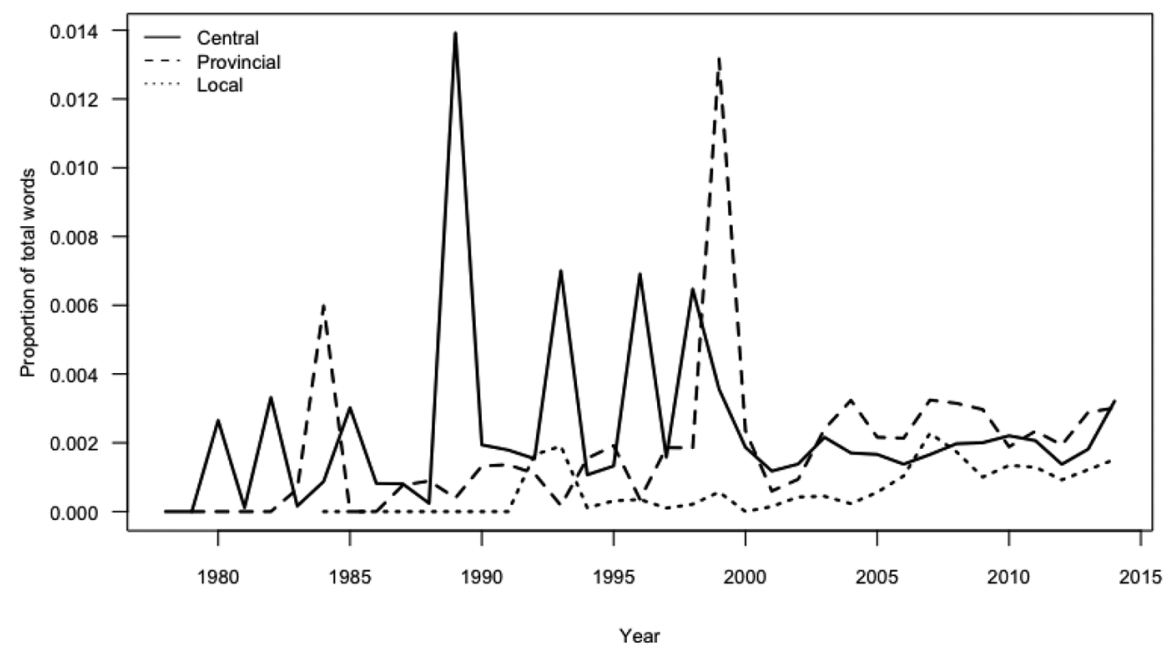

Figure 3. Prevalence of the word investment in central, provincial, and local transportation equipment industry regulations.

abroad into our province to invest and build new factories." The policy stated that "all key enterprises should increase investment in research and development ... and form large-scale production as soon as possible... . Priority should be given to the inclusion of NEV projects in provincial key projects, and preference should be given in the allocation of production factors such as land and capital." 56 Such rhetoric clearly reflects an extensive development mindset and a tendency to concentrate resources in privileged sectors. Meanwhile, in contrast to the State Council's stress on developing the services side of the NEV industry (the word "service" is mentioned 15 times in the national policy), the Hebei policy makes only one mention of services. And whereas the national policy emphasized holistic development by using the concept of "management" (guanli 管理) 18 times, including the need for strengthening "management systems," considering "management needs" and developing "management measures," the provincial document used the word "management" only three times, two of which referred to "battery management."

While variation in the precise wording of NEV implementing policies adopted by different provinces is to be expected, the Hebei government's NEV approach is more typical than exceptional. Indeed, province-level emphasis on investment and large-scale production over other aspects of the national NEV policy soon led to familiar problems of excess capacity in the sector. By 2017, the central government had issued new investment guidelines for the automotive industry, 
urging against "blind and duplicative investment" and seeking to tighten investment and licensing guidelines for NEVs. ${ }^{57}$

The provinces' tendency to approach industrial development reductively as a resource mobilization problem is also seen outside the NEV industry. Many provinces that have attempted to groom strategic emerging industries lack the necessary human capital endowments or industrial ecosystems for a comparative advantage in these sectors. ${ }^{58}$ For example, the three provinces in China's northeastern rust belt, which historically specialized in agricultural industry and heavy industry, all set targets to develop multi-billion-dollar artificial intelligence sectors by $2020 .^{59}$ Absent suitable regional conditions, however, such channeling of provincial investment to cutting-edge high-technology industries is likely to prove wasteful, exacerbating rather than curbing the reliance on investment for growth creation and hampering efforts to coordinate industry upgrading. Like our findings above, such trends reflect provincial governments' pursuit of rapid industrial expansion for its own sake-a trend that has ironically become more, not less, pronounced over two decades of recentralization.

\section{Rural Development: The Repurposing of Provincial-Administration- of-Counties Reforms}

The rural economy is another realm where provincial influence over the allocation of resources and policy support has complicated China's efforts to correct developmental imbalances. After years of mounting urban-rural inequality and rural discontent, the plight of the countryside and county-level economies attracted growing attention from central leaders. Particularly after $\mathrm{Hu}$ Jintao and Wen Jiabao took power in 2002, Beijing stepped up efforts to promote rural development and social welfare. One nationwide strategy was to separate county-level units from the management of prefecture-level city governments. Concerns had mounted over the "city-leading-county" administrative system popularized after the 1980s that gave city authorities fiscal and administrative jurisdiction over the surrounding counties. Critics argued that this system had led to an economic stranglehold over counties by cities and an overconcentration of investment and public spending

57. National Development and Reform Commission and Ministry of Industry and Information Technology, "Opinion on Improving the Management of Automobile Investment Projects" (2017), accessed August 11, 2019, http://www.miit.gov.cn/n1146285/n1146352/n3054355/n3057585/n3057592/c5683037 /content.html.

58. Dan Prud'homme, "Dynamics of China's Provincial-Level Specialization in Strategic Emerging Industries," Research Policy 45, no. 8 (2016): 1586-1603.

59. Jacqueline Ives and Anna Holzmann, "Local Governments Power Up to Advance China's National AI Agenda," Merics Blog_European Voices on China (2018), accessed February 8, 2019, https://www .merics.org/en/blog/local-governments-power-advance-chinas-national-ai-agenda. 
in urban areas. ${ }^{60}$ With encouragement from Beijing, provinces launched experiments in the early and mid-2000s to expand certain counties' economic powers and to remove counties from the fiscal management of prefecture-level cities. China's Eleventh and Twelfth Five-Year Plans went further, calling for experimentally placing some of the counties under broader provincial administrative oversight. ${ }^{61}$

While Beijing gave its blessing to both fiscal- and administrative-style PAC reforms, provincial governments designed and implemented the reforms in ways compatible with province-level interests and economic imperatives. Between 2002 and 2014, the majority of China's provinces carried out reforms that put at least some of their counties and county-level cities under more direct provincial supervision in terms of fiscal and/or administrative affairs. ${ }^{62}$ In many provinces, administrative-style PAC reforms designed to enhance the economic authority of counties transferred some administrative and economic management privileges that had previously belonged to prefecture-level city authorities to county-level governments. ${ }^{63}$ However, counties now had to consult with or seek approval from province-level authorities on a greater number of socioeconomic development decisions, giving provinces more sway over counties' access to resources and investment approvals. Meanwhile, when it came to the fiscal-style PAC reforms adopted in various provinces, ${ }^{64}$ provincial authorities assumed fiscal oversight of targeted counties. Although counties now faced less risk that prefecture-level city authorities would extract additional revenues or withhold resources, counties became more reliant on the favor of provincial authorities, who could henceforth determine the sharing rates for local fiscal revenues and arrangements for downward fiscal transfers. Such reforms thus positioned provincial governments to capture and reallocate more of the economic and fiscal benefits of county-level growth. This was the case, for instance, with Jiangsu's 2008 "Circular on Adjusting the Fiscal Management Mechanism for the Tax-Sharing System," which allowed counties to keep certain tax revenue streams but also raised the province's share

\footnotetext{
60. Laurence Ma, "Urban Administrative Restructuring, Changing Scale Relations, and Local Economic Development in China," Political Geography 24 (2005): 477-97.

61. Luo Xiaolong, Cheng Yeqing, Yin Jie, and Wang Ying, "Province-Leading-County as a Scaling-Up Strategy in China: The Case of Jiangsu," China Review 14, no. 1 (2014): 125-46.

62. Chung, Centrifugal Empire, 51. By 2010, 50.2 percent of counties were subject to provincial administration.

63. See, e.g., Hunan Provincial Party Committee Office and Hunan People's Government Office, "Guanyu kuoda xian (shi) jingji guanli quanxian de tongzhi" [Circular regarding expanding the economic management powers of counties (cities)] (2005), http://www.chinaacc.com/new/63/74/117/2006/2/ji6632145 9451522600215228-0.htm.

64. See, e.g., Jiangsu Provincial Government, "Guanyu shixing sheng zhi guan xian caizheng guanli tizhi gaige de tongzhi" [Circular regarding the implementation of provincial administration of counties fiscal management system reform], (2007), http://www.js.gov.cn/art/2007/10/23/art_47037_2682099.html; and Shaanxi Provincial Government, "Guanyu shixing sheng guan xian caizheng tizhi gaige shidian de tongzhi” [Circular regarding the implementation of provincial-administration-of-counties fiscal system reform test points], (2006) http://www.chinalawedu.com/news/1200/22016/22019/22073/2007/1/zh46729324619117002663-0.htm.
} 
of value-added tax and boosted the provincial government's share of urban landuse taxes. ${ }^{65}$ Across China more broadly, county-level fiscal indicators tended to improve as a result of fiscal PAC reforms, usually at the expense of prefecturelevel governments. But the province-level share of fiscal revenues and expenditures often increased as well, making provinces co-beneficiaries. ${ }^{66}$

Moreover, provincial governments often used administrative-style PAC reforms to channel resources and policy support to top-performing localities, an approach at odds with Beijing's stated concerns about rural livelihood and more balanced growth. To be sure, fiscal-style PAC reforms were often extended to economically weaker counties. In provinces such as Hunan and Jiangsu, for example, virtually all counties and county-level cities were included in such reforms, and in some provinces, like Shaanxi, the counties selected for fiscal PAC reforms were poorer than average. ${ }^{67}$ By contrast, however, administrative-style PAC reforms often favored wealthier, more industrialized counties. In Hunan and Shaanxi, the counties targeted for upgraded economic and administrative powers tended to be above-average in GDP and GDP per capita. While some elements of $\mathrm{Hu}-$ nan's 2005 reforms to expand counties' economic management powers applied to all counties, the most significant preferential policies were reserved for a subset of "economically strong counties" that met restrictive performance criteria. ${ }^{68}$ Four out of the five county-level units in Hunan able to qualify at the outset were located within the boundaries of Changsha, Hunan's provincial capital, which was already far and away the wealthiest part of the province. Similarly, in Shaanxi, the 21 counties targeted by a 2007 "Decision on Expanding the Economic Management Powers of Certain Counties (Cities)" and a follow-on 2009 policy tended to be wealthier and fiscally stronger than average. ${ }^{69}$ In addition, experiments with more comprehensive administrative-style PAC reforms in provinces like Jiangsu also tended to focus on already privileged places. For instance, in 2011 Jiangsu announced it would pilot these reforms in Kunshan, a county-level city under the

65. China Reform Forum, "Jiangsu tuijin sheng zhi guan xian (shi) caizheng tizhi gaige yanjiu” [Jiangsu pushes forward research on fiscal provincial-administration-of-counties institutional reform] (2013), http:// www.chinareform.org.cn/area/inshore/Forward/201010/t20101014_46763.htm.

66. Pei Li, Yi Lu, and Jin Wang, "Does Flattening Government Lead to Improved Economic Performance? Evidence from China," Journal of Development Economics 123 (2016): 18-37.

67. China Data Online, All China Data Center of the University of Michigan, accessed 2018, www .chinadatacenter.org; author's calculations. See also Jiangsu Provincial Government, "Circular” Shaanxi Provincial Government, "Circular" and Hunan Provincial Party Committee, Hunan People's Government, "Guanyu wanshan caizheng tizhi tuixing 'sheng zhi guan xian' gaige de tongzhi” [Circular on perfecting fiscal system to push forward provincial-administration-of-counties reform] (2010), http://www .hunan.gov.cn.

68. To win this designation, counties had to have a 2004 GDP in excess of 4 billion yuan and 2004 fiscal revenue above 300 million yuan. See Hunan Provincial Party Committee General Office, "Circular."

69. China Data Online; author's calculations. See also Shaanxi Provincial Government, "Guanyu kuoda bufen xian (shi) jingji guanli quanxian de jueding" [Decision on expanding the economic management powers of certain counties (cities)] (2007), http://www.china.com.cn/guoqing/gbbg/2011-11/15/content _23922403.htm. 
jurisdiction of Suzhou City; Taixing, under Taizhou City; and Shuyang, under Suqian City. ${ }^{70}$ The province subsequently channeled resources to and tightened administrative control over these three economically strategic counties. Kunshan was among the wealthiest county-level units in the whole country, an industrial and commercial hub positioned between the urban hubs of Suzhou and Shanghai. Taixing, located along the northern bank of the Yangtze River, was a smaller economic center, but had considerable development potential given its advantageous location. Shuyang, in northern Jiangsu, was the host to a regional branch of the Kunshan New High-Tech and Industrial Park. ${ }^{71}$ This was therefore a classic case of betting on the strong.

This brief look at different types of PAC reforms thus suggests that, as in the industrial policy realm, provinces have enjoyed an expanding influence over the development space of localities and have used this in ways that deviate from central policy agendas. Although scholars such as John Donaldson are right to stress the benefits the reform has had for county-level development in some provinces, the reform has also had problematic consequences. ${ }^{72}$ As Jae Ho Chung notes, provinces have been given fiscal and/or administrative oversight of larger numbers of counties than they can realistically manage. ${ }^{73}$ And most importantly, as we have shown, while reforms were notionally aimed at helping underdeveloped rural areas, provincial authorities in many cases gave the greatest policy and financial support to economically strong counties. Thus the economic consequences of such reforms have been mixed: although fiscal PAC reforms tended to improve countylevel finances, they led to slower economic growth for counties on the whole. ${ }^{74}$ The uneven outcomes and the resentment of cities over their loss of power and resources have been factors in the slow-down and partial reversal of such reforms during the 2010 s decade. $^{75}$

\section{Foreign Economic Relations: The Provincial Path to the Belt and Road Initiative}

The realm of foreign economic relations illustrates how provinces' developmental drive also shapes the formulation of national-level policy. Since the 1980s, China's

\footnotetext{
70. See Jiangsu Provincial Party Committee and Jiangsu People’s Government, "Yinfa 'guanyu kaizhan sheng zhi guan xian tizhi gaige shidian gongzuo de yijian' de tongzhi” [Circular on dissemination of "Opinion on launching PAC system reform test point work"] (2011), http://govinfo.nlc.gov.cn/jssfz/jszb /906783a/201201/t20120109_1283335.shtml?classid $=456$.

71. Shiuh-Shen Chien, "New Local State Power through Administrative Restructuring-A Case Study of Post-Mao China County-Level Urban Entrepreneurialism in Kunshan,” Geoforum 46 (2013): 103-12.

72. See Donaldson, "China's Administrative Hierarchy," 125.

73. Chung, Centrifugal Empire, 51.

74. Li et al., "Does Flattening Government Lead to Improved Economic Performance?"

75. Chung, Centrifugal Empire, 100-103.
} 
liberalization of foreign investment in China and trade has given provinces opportunities to pursue their interests within the framework of China's foreign economic relations and even to shape the contours of those relations. ${ }^{76}$ Notwithstanding governance recentralization in recent decades, provinces have maintained an influential position in the foreign economic realm, deploying a range of tactics to advance their own interests, from resisting national initiatives to trailblazing ahead of the central government. ${ }^{77}$ One consequence of such provincial opportunism is that, while national leaders have sought a strategic extension of economic links to the global economy, foreign engagement has often occurred in a frenetic, uncoordinated manner.

Nowhere is this tendency more apparent than with the Belt and Road Initiative, Xi Jinping's signature policy program-a program so high-profile that it was even written into the Party constitution. ${ }^{78}$ First announced in 2013, the BRI aims to bring Chinese investment and trade deals to a loose constellation of countries along historical Silk Road routes stretching westward from China into Central Asia and Europe and southward through maritime routes from Southeast Asia to South Asia and Africa. A 2015 interministerial document outlined the BRI's policy priorities and mechanisms, emphasizing cross-border connectivity and the simultaneous pursuit of international development cooperation on various geographic and functional fronts. ${ }^{79}$

However, the BRI's form and content cannot be understood without accounting for the role of Chinese provinces. One key avenue of provincial influence is the link between provinces' focus on infrastructure megaprojects and the BRI's emphasis on infrastructure connectivity between China and the wider reaches of Asia, Africa, and Central Europe. Provinces play a key role in large-scale transport development. While the boundary-crossing nature and huge capital requirements of railroads and highways put these infrastructure megaprojects beyond the reach of most city and county-level governments, the central government on its end lacks the regional expertise and administrative capacity to orchestrate such projects alone. Provincial authorities, in contrast, are well situated to mobilize the necessary resources and to play a coordinating role for such large-scale,

76. Peter T. Y. Cheung and James T. H. Tang, “The External Relations of China's Provinces," in The Making of China's Foreign and Security Policy in the Era of Reform, 1978-2000, ed. David M. Lampton (Stanford, CA: Stanford Unversity Press, 2001), 91-122.

77. Audrye Wong, "More Than Peripheral: How Provinces Influence China's Foreign Policy," China Quarterly, no. 235 (2018): 735-57.

78. “'Belt and Road' Incorporated into CPC Constitution” (2017), accessed January 31, 2018, http:// www.xinhuanet.com/english/2017-10/24/c_136702025.htm.

79. National Development and Reform Commission, Ministry of Foreign Affairs, and Ministry of Commerce of the People's Republic of China, "Vision and Actions on Jointly Building Silk Road Economic Belt and 21st-Century Maritime Silk Road" (2015), accessed December 10, 2019, https://reconasia -production.s3.amazonaws.com/media/filer_public/e0/22/e0228017-7463-46fc-9094-0465a6f1ca23/vision _and_actions_on_jointly_building_silk_road_economic_belt_and_21st-century_maritime_silk_road.pdf. 
long-distance construction projects. ${ }^{80}$ Furthermore, because such projects are linked with urban and industrial development, they align well with provincial governments' pursuit of growth opportunities.

To trace how provinces' promotion of infrastructure development has prefigured and influenced the policy content of the BRI, we have examined the development plans of several key BRI provinces in the years before the BRI was launched (in 2013). Yunnan, Sichuan, and other provinces have been pursuing cross-border economic and infrastructural links for decades. Yunnan, a landlocked province in southwestern China, has advocated greater river-based and overland connectivity with neighboring countries in southeast and south Asia since the 1990s. ${ }^{81}$ In 2000, the Yunnan government issued a five-year plan that discussed a "Grand Routeway" strategy for regional engagement. ${ }^{82}$ The document, declared an intention to "establish Yunnan as the frontier of external opening in the southwest and as the nation's grand routeway with Southeast and South Asia." Subsequently, in 2008, the province issued a "Circular on Participating in Economic Cooperation Work" that called for "vigorously pushing the construction of a Greater Mekong Subregion economic corridor" and a focus on "transport infrastructure as a main area of cooperation, involving roads as well as railways, shipping, cargo transportation, and port infrastructure building." 83 Such an emphasis on multicountry regional transport connectivity foreshadowed the BRI.

Similar examples from the developmental plans of other provinces abound, all of which predate Xi Jinping's formal announcement of the BRI in 2013. For example, Sichuan province's "Twelfth Five-Year Plan for Economic and Social Development," issued in October 2010, discussed the implementation of the province's "three directions of expansion and four levels of promotion" strategy. One part of this was to expand cooperation with ASEAN and South Asian nations by building a "Grand Routeway" in the Southwestern sea via a "Southern Silk

80. Yin Nor Tjia ("The Unintended Consequences of Politicization of the Belt and Road's China-Europe Freight Train Initiative," China Journal, in this issue) shows how this transcontinental set of routes was started by a few inland provinces to provide incentives for foreign-owned companies to move to their provincial capitals from China's coastal region.

81. See, e.g., Yunnan Provincial Party Committee and Yunnan Provincial Government, "Guanyu jinyibu kuoda duiwai kaifang de ruogan yijian" [Certain opinions on further expanding external liberalization] (1998), http://www.pkulaw.cn.

82. See Yunnan Provincial Government, "Guomin jingji he shehui fazhan dishige wunian jihua he dao 2015 nian changqi guihua jiben sixiang" [Basic thought on the tenth five-year plan and 2015 long-term plan for economic and social development] (2000), http://www.pkulaw.cn.

83. Yunnan Provincial Government Office, "Guanyu yinfa Yunnan canyu Lancang jiang-Meigong he ciquyu jingji hezuo gongzuo yijian de tongzhi" [Circular on Opinion regarding Yunnan's participation in economic cooperation work in the Lancang-Mekong river] (2008), http://www.pkulaw.cn. Also, for a more detailed examination of Yunnan's outward economic policies, see Tim Summers, “China's 'New Silk Roads': Sub-national Regions and Networks of Global Political Economy," Third World Quarterly 37, no. 9 (2016): 1628-43. 
Road." ${ }^{4}$ Policies issued by the Inner Mongolia provincial government in 2008 and 2012 repeatedly emphasized the province's link to the "Eurasian land bridge" and the need to expand transportation lines with Russia and Mongolia. ${ }^{85}$ Xinjiang issued an opinion in 2005 that similarly discussed the need to develop westward via rail and port infrastructure improvement, so as to establish a "new Eurasian land bridge." ${ }^{\circ 6}$ Guangxi's 2009 "Circular on Deepening the Reform of the Economic System" highlighted as priorities the China-ASEAN Free Trade Agreement and economic cooperation in the Beibu Gulf and Mekong River regions, as well as building an "economic corridor" between Singapore and Guanxi's provincial capital Nanning. Subsequently, the province's "Going Out" strategy in 2011 focused on developing engineering projects and infrastructure construction in ASEAN and the Beibu Gulf region. ${ }^{87}$ In their focus on southern and northwestern trade and investment routes, as well as their emphasis on economic connectivity, regional infrastructure, and provincial capital cities, these various documents show how the contours of the BRI were influenced by preexisting provincial policies rather than designed top-down by central agencies.

Much of this subnational activism, or what Li Mingjiang terms "local liberalism," 88 accelerated in the context of a more permissive national policy environment, with central policies in the late 1990s and early 2000s emphasizing the development of western provinces and the forging of a free-trade agreement with ASEAN. But even subsequently, under a more assertive central party-state, provinces have been able to promote their development interests and influence national policies. A direct reflection of provincial influence in the BRI is Beijing's 2015 "Vision and Actions" document, which incorporated the substance of the preexisting provincial documents. The priorities and projects highlighted in this

84. Sichuan Provincial Government Office, "Guanyu yinfa Sichuan sheng guomin jingji he shehui fazhan 'shi'er wu' guihua jiben silu de tongzhi” [Circular regarding the basic thinking on the twelfth Five-Year Plan for economic and social development] (2010), http://www.pkulaw.cn.

85. Inner Mongolia Autonomous Region Government, "Neimenggu zizhiqu renmin zhengfu guanyu zuohao chengjie fada diqu chanye zhuanyi de zhidao yijian" [Guiding opinion on undertaking the industrial transformation of developed regions], May 13 2008; and Inner Mongolia Autonomous People's Government, "Guanyu jiakuai tuijin manzhouli guojia zhongdian kaifa kaifang shiyanqu jianshe de ruogan yijian" [Certain opinions on speeding up and advancing the construction of the important experimental zones on development and opening up in Manzhouli], January 9, 2013, http://www.pkulaw.cn.

86. Xinjiang Autonomous Region Government, "Guanyu jinyibu zuohao shenghuoqu wuzi yunshu zuzhi xietiao gongzuo de yijian" [Opinion on improving the organizational and coordination work for transporting goods and capital] (2005), http://www.pkulaw.cn.

87. Guangxi Government, "Guangxi Zhuangzu zizhiqu renmin zhengfu guanyu yinfa 2009 nian Guangxi shenhua jingji tizhi gaige gongzuo ruogan yijian de tongzhi” [Circular on deepening the reform of the economic system], July 10, 2009; and Guangxi Autonomous People’s Government, "Guangxi Zhuangzu zizhiqu renmin zhengfu guanyu jiakuai shishi "zouchuqu" zhanlüe de yijian" [Opinion on accelerating the implementation of the "Going Out" strategy], May 19, 2011, http://www.pkulaw.cn.

88. Li Mingjiang, "Local Liberalism: China's Provincial Approaches to Relations with Southeast Asia," Journal of Contemporary China 23, no. 86 (2014): 275-93. 
central document mirror many of those long advocated by provinces-from infrastructure connectivity to regional trade and investment. A lengthy section of the document on the role of subnational governments stresses the nodal positions of provincial capital cities in the BRI, and it reemphasizes the same initiatives that some provinces had long advocated. ${ }^{89}$

Just as provincial initiatives fed into the launch of the BRI, provincial activism has shaped its implementation. Ever since the BRI was elevated to a national priority, state support for associated projects has grown dramatically. As noted, provinces have both the motives and the means to take advantage of such central state largesse, redefining and repurposing national-level policies in ways that serve their own local interests. With the provinces struggling to maintain economic growth and manage excess industrial capacity, they have shown a keen interest in BRI-related opportunities. By July 2015, 21 out of 31 provinces had already developed their own BRI plans in a bid to draw central funds to their region. ${ }^{90}$ More recent reports suggest that competition to secure BRI resources has led them to subsidize a range of commercially unwarranted projects. Interprovincial competition in building rail links with Europe, for example, has led to wasteful duplication at the cost of over $\$ 300$ million in subsidies. ${ }^{91}$ Provincially driven development schemes such as the creation of a sprawling Lanzhou New Area in Gansu have taken advantage of their geographic alignment with the BRI to justify enormous investments in an already-privileged provincial capital. ${ }^{92}$ In short, provincial efforts to mobilize new development space have found rich opportunities in the ambitious yet vaguely defined BRI, producing many of the same types of economic irrationalities and coordination problems seen in other policy realms.

\section{CONCLUSION}

Throughout successive periods of recentralization since the 1990s, including the aggressive centralism of the $\mathrm{Xi}$ administration, China's provinces have come to play an enlarged-rather than diminished-role in economic governance and have left their mark on national policy outcomes. Provinces' position in China's state architecture as gatekeepers between resource-hungry localities and a resourcerich center has made them key brokers of development space for various industries and regions.

89. National Development and Reform Commission et al., "Vision and Actions."

90. Economist Intelligence Unit, "Provinces Enthusiastically Embrace 'One Belt, One Road'” (2015), http://country.eiu.com/article.aspx?articleid = 1473361731.

91. Jonathan Hillman, "China's Belt and Road Is Full of Holes," Center for Security and International Studies (CSIS) Brief (2018), http://www.csis.org.

92. Simon Denyer, "Along the Silk Road, a City Built on Sand Is a Monument to China's Problems," Washington Post, May 29, 2016. 
We have not only emphasized the enduring importance of China's provinces in economic governance; we have also presented an argument about how provincial authorities use this influence. The quest for development space leads provinces to favor an extensive and opportunistic mode of growth-one often at odds with Beijing's objectives. It has been seen that in industrial policy, the central government's efforts to curb excess capacity and shift toward a consumption-based growth model have been hindered by provinces' continued focus on large-scale investments. In rural development, fiscal and administrative reforms meant to help poor counties have ended up strengthening provincial control over resources and perpetuating inequalities. And in foreign economic policy, provinces' aggressive pursuit of new opportunities to develop infrastructure and outward connectivity has shaped the contours of the BRI, the signature initiative of the Xi era.

Evidence from other policy realms similarly points to the enduring, if evolving, power of provinces amid political and administrative recentralization. As Genia Kostka and Jonas Nahm observe, the Xi administration's efforts to combat environmental pollution have involved stronger central guidance than before but remain dependent on provincial cooperation. ${ }^{93}$ In major initiatives such as the campaign against air pollution in the Beijing-Tianjin-Hebei region, for example, the center has had little choice to but rely on provincial authorities for implementation. Even in a case where the center has tried to control policy design, provided much of the funding, and created strong accountability mechanisms, its own limited organizational capacity and information remain key constraints. ${ }^{94}$

Our analysis thus underscores a paradox of China's recent waves of recentralization. Even with Xi's consolidation of political and ideological power, administrative restructuring has continued to vest great de facto power at the provincial level, and Beijing's sweeping policy initiatives have given provinces new opportunities to mobilize development space for their cities and industries. As Beijing simultaneously empowers provinces and tightens its oversight of them, it is gambling that the provinces will faithfully execute central mandates. But, as we have shown, provincial authorities remain highly protective of their own interests and are deeply invested in a growth model founded on expanding development spacethe very same input-maximizing and resource-intensive development that Beijing hopes to rein in.

\footnotetext{
93. Genia Kostka and Jonas Nahm, "Central-Local Relations: Recentralization and Environmental Governance in China," China Quarterly, no. 231 (2017): 567-82.

94. Christine Wong and Valerie Karplus, "China’s War on Air Pollution: Can Existing Governance Structures Support New Ambitions?” China Quarterly, no. 231 (2017): 662-84.
} 